\title{
GIS: A USEFUL TOOL FOR MANAGING OF TRANSBOUNDARY AQUIFERS: A CASE STUDY FROM PRESPA LAKE BASIN
}

\author{
Kiri E. \\ Institute of Geosciences, Energy, Water and Environment, UPT, Albania, \\ emanuelakiri@yahoo.com
}

\begin{abstract}
Prespa Lake Basin is a transboundary basin that's shared between Albania-GreeceFYROM. This region has a very complicated geology. The main aquifer systems are developed in carbonate rocks (karst aquifers) crossing international borders (transboundary aquifers). A map was constructed in GIS environment clearly display that each geologic age has one index, in one polygon, with the respective geological formation. The map was first digitalized with an AutoCAD program and then all the layers were exported in the program mentioned above. Not only does this map represent the hydrogeological features of the area but it also serves as a database of general characteristics, such as, the rock type, the infiltration coefficient, the yield of wells and springs, groundwater resource and permeability can be found on this base. Furthermore, chemical data can be added to the map, supplying more information on the surface and groundwater. Geographical Information Systems (GIS) is a useful tool for water resources management in the frame of international cooperation and coordination.
\end{abstract}

Keywords: Hydrogeologic map, GIS, Prespa Lake basin, Transboundary aquifers.

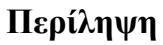

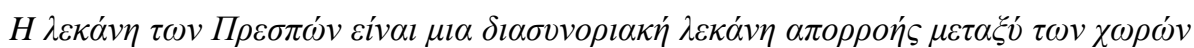

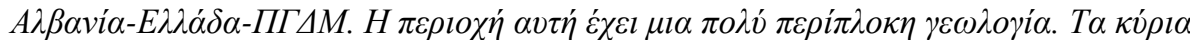

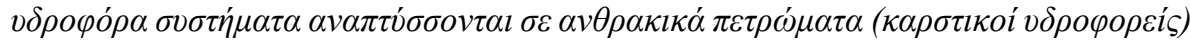

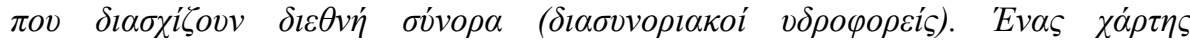

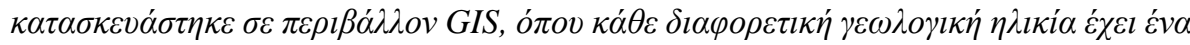

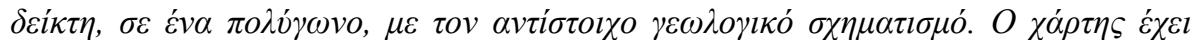

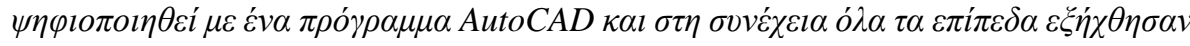

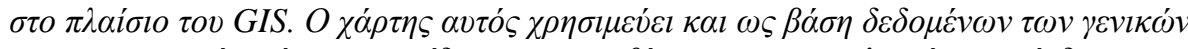

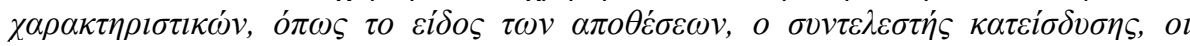

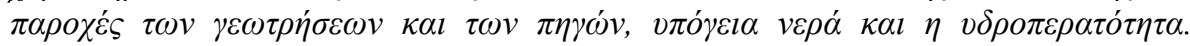

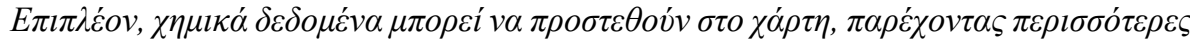

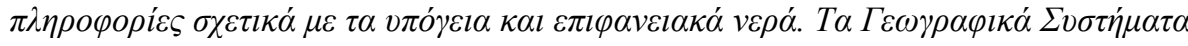

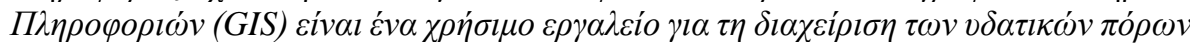

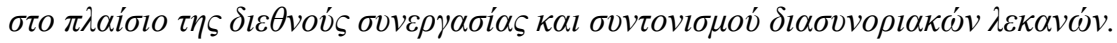

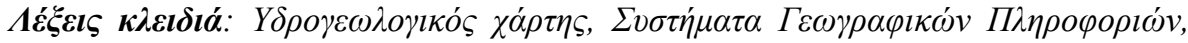

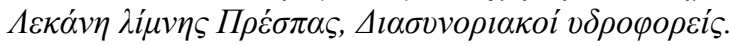




\section{Introduction}

Groundwater is very important for agriculture and domestic use, as well for maintaining baseflow of rivers and sustaining ecosystems. Many countries share aquifer systems with their neighbours, which are called transboundary aquifers. The management of transboundary basins is expected to play an important role in water security in the future and require high levels of international cooperation and coordination.

Geographical Information Systems (GIS) is a useful tool for water management. This program appears helpful and practical to be used by multidisciplinary engineers and water scientists. According to Sheppard (2004) growing rapidly since their development in the 1970s, the GIS are now used in a variety of private and public organizations and institutions, and more recently by individuals. GIS can be used to analyze, make decisions, and emerge geographic information. In essence, GIS are computerized information systems composed of hardware and software. These systems may be used to store, alter, and map geo-referenced databases in a way that the researcher may make the most use out of the immense amount of data.

GIS is a powerful and useful program and its usage will increase over time. It is very easy to construct thematic maps, e.g. hydrogeological, hydrochemical, vulnerability maps. These maps are expected to be useful not only for the specialists of the field but also for water policy makers, local administrators and stakeholders (Voudouris et al., 2010).

The aim of this work is to illustrate the hydrogeological map of the Prespa Lake Region using GIS. Firstly, the general hydrogeological characteristics of the study area are presented. A large part of this research was carried out within the framework of the MSc Thesis of Emanuela Kiri.

\section{Study site}

Prespa Lake is located in the southeast part of Albania, in the northeast part of Greece and in the southwest part of the FYROM (Fig. 1). Prespa Lake is situated in the southeastern Mediterranean mountainous area, which is characterized by cold winters. The air temperature ranges from 7-10 0C during the cold period and up to $18.80 \mathrm{C}$ during the summer months. Both Big and Small Prespa are situated at $850 \mathrm{~m}$ above the sea level. The surface areas for Big and Small Prespa are $253.6 \mathrm{~km}^{2}$. The average maximum depth of Big Prespa Lake is $54 \mathrm{~m}$ and the minimum is $18 \mathrm{~m}$ (Ramsar, 2000 and KfW, 2004). The lakes are connected by a small channel, which passes through alluvial deposits which separate these lakes (this part is located in Greece). The Small and Big Prespa Lake and the Ohrid Lake are a common hydraulic system shared between Albania, FYROM and Greece (Fig. 2). The water level decline of Prespa Lake has been one of the most important recent point of the study area (Eftimi, 2003).

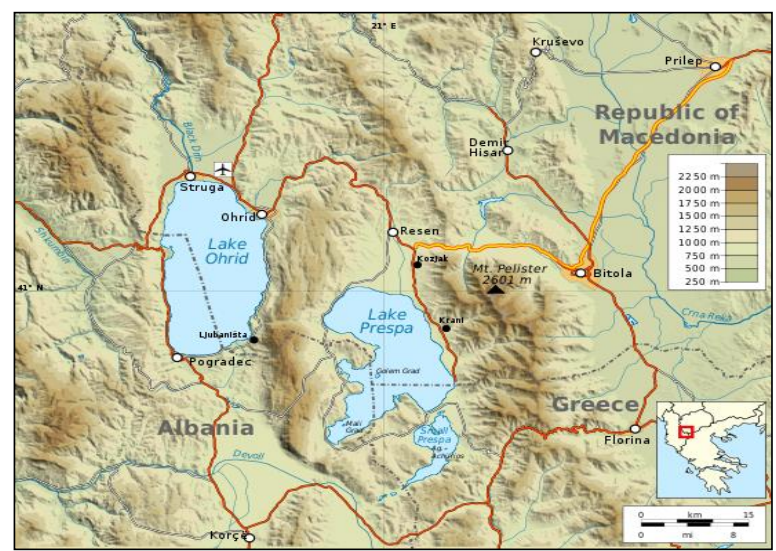

Figure 1 - Topographic map of the study area (Prespa and Ohrid Lake Region) https://commons.wikimedia.org/wi. 


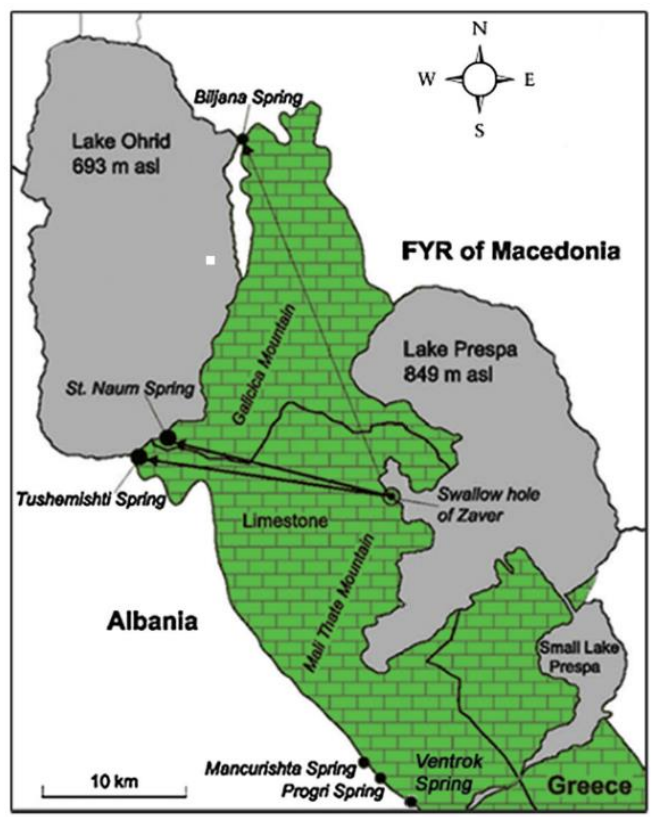

Figure 2 - Hydraulic system of Lake Ohrid and Lake Prespa (Matzinger et al., 2006). The bl ack arrows show the proven underground connection.

\section{Materials and Methods}

The map developed by the Geographic Information System (GIS) is the latest and the most detailed. The map was designed to be the most functional and simple for use by all. GIS stores two kinds of information: geographic coordinate data (spatial data) and attribute data. The GIS is a device for standardizing and storing the data, analyzing relationships in the data to create new information, and displaying the data in a map or a report. Spatial data represent features that have a known location on earth. When working with maps, all spatial data may be defined as one of three types: points (no dimension), lines (one dimension), and areas (two dimensions). This representation of points, lines and areas is how spatial data is presented on maps and how the data is usually stored in the computer environment of a GIS (Cox and Gifford, 1997). The database of the map has been explained in two parts, since the first one was for the hydrogeologic aspect, in which all the existing data has been included. In the second part, the map was enriched with chemical data of the region.

The Geographic Information System (GIS) technology is a critical methodology to understand, represent, manage, and communicate the many aspects of physical and man-made landscapes and to better understand the earth as a system. A GIS is a system for the management, analysis, and display of geographic knowledge, which is represented using a series of information data. In a GIS, homogeneous collections of geographic objects are organized into a series of data themes, or layers, that cover a given map, for example: roads, rivers, place names, buildings, parcels, political boundaries, surface elevation, and satellite imagery (Benedikt et al., 2002).

The main application in ArcGIS is ArcMap and is used for all mapping and editing as well as for map-based studies and analysis. ArcMap represents geographic information as a collection of layers and other elements on the map (Ranger et al., 2002). Common map elements include the data frame containing map layers for a given area, plus a scale bar, north arrow, title, descriptive text, and a legend symbol as shown in Fig. 3. 

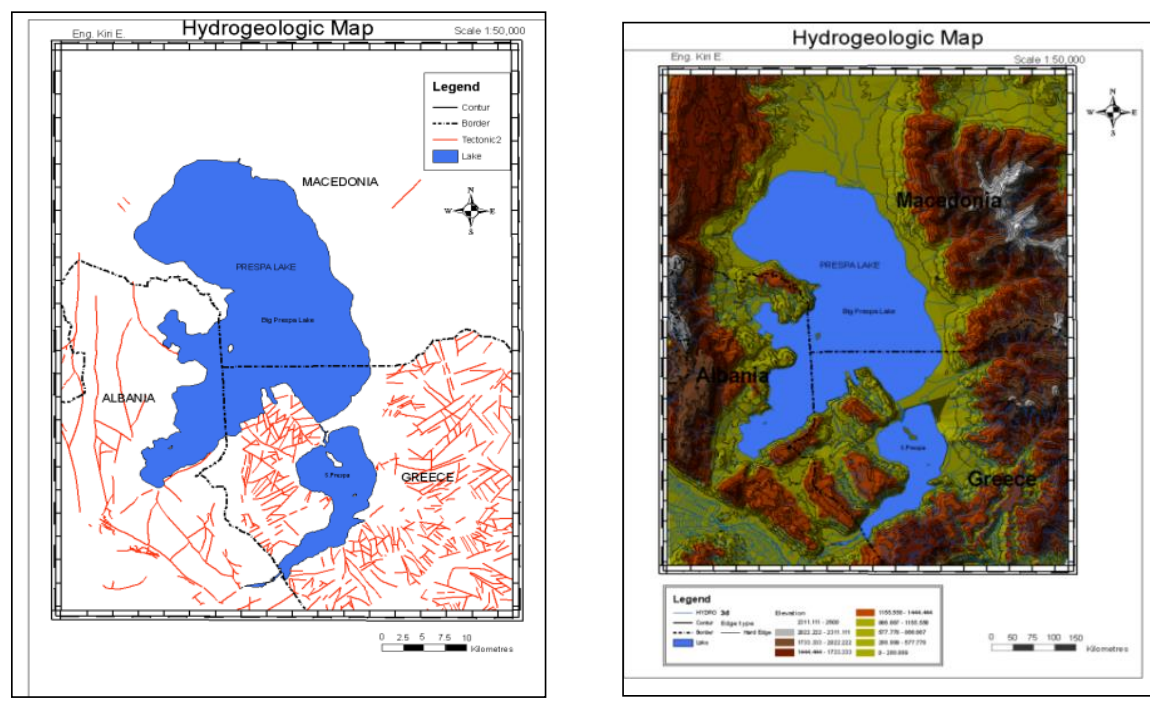

Figure 3 - Tectonic (left) and 3D view of the geomorphological (right) map of Prespa Lakes.

The hydrogeologic map in scale 1:50,000 is taken from the archive of Albanian Geological Survey (Fig. 4). It was processed in GIS program, where data are added according to map's profile. The hydrogeologic map scale 1:50,000 is initially digitized (Kiri, 2010) and later additions have been made to the attribute table of polygons mentioned above, such as hydrogeology (hydrogeological classification). In Fig. 5, the hydrographic network of the study area is shown.

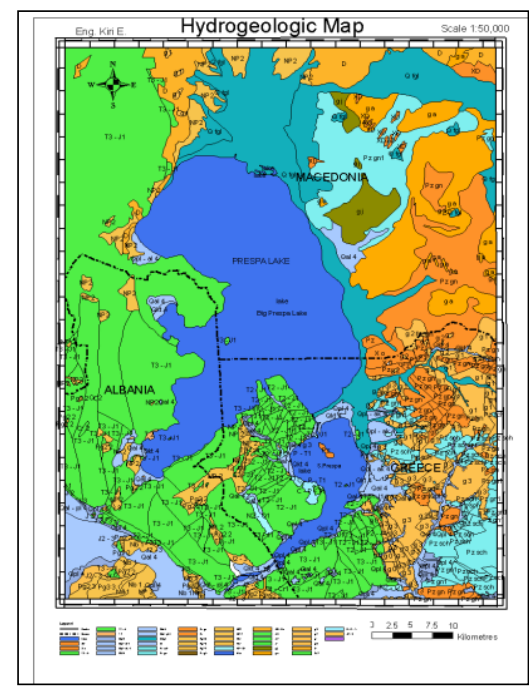

Figure 4 - Hydrogeological map in GIS rogram (Prespa Lake region).

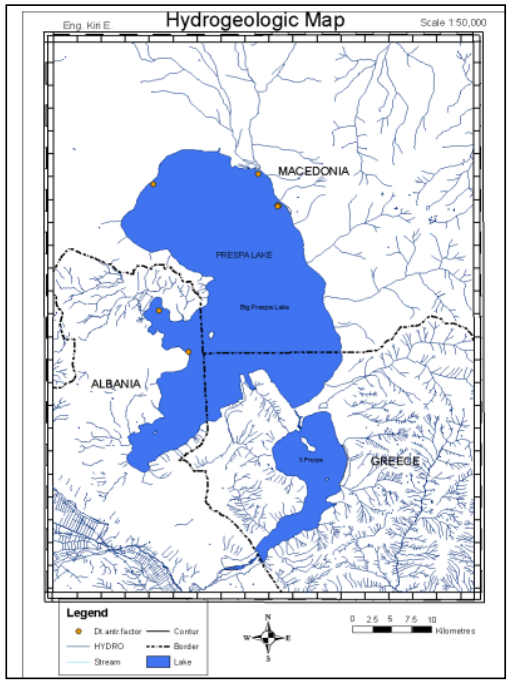

Figure 5 - The hydrologic system in the Prespa Lake region.

The digitalization of the curriculum mapping was done in AutoCAD 2005 and later relocated to the GIS program. The attribute table of polygons was also completed, which defines the ranges of hydrogeological data (Table 1) in ArcMap and then the metadata for each map layer in ArcCatalog were created. By observing the attribute table of the ranges one can obtain a clear picture of all hydrogeological data in the region of Prespa. This is helpful to a hydrogeology specialist because there is data on each polygon explaining the water deposits, which itself represents a particular geological age and that age is represented by the respective deposits. 
Table 1 - Attribute Table (Hydrogeological general classification of the map).

\begin{tabular}{|c|c|c|c|c|c|c|c|c|}
\hline Index & $\begin{array}{c}\text { Geological } \\
\text { age }\end{array}$ & Lithology & $\begin{array}{l}\text { Hydrogeology } \\
\text { Classification }\end{array}$ & $\begin{array}{c}\text { Infil. } \\
\text { Coeff. } \\
\% \\
\end{array}$ & $\begin{array}{c}\text { GW } \\
\text { Resource }\end{array}$ & $\begin{array}{l}\text { Perme } \\
\text {-ability }\end{array}$ & $\begin{array}{c}\text { Yield } \\
\text { of } \\
\text { wells }\end{array}$ & $\begin{array}{l}\text { Yield of } \\
\text { springs }\end{array}$ \\
\hline $\mathrm{T}_{3}-\mathrm{J}_{1}$ & $\begin{array}{l}\text { Upper } \\
\text { Triassic- } \\
\text { Lower } \\
\text { Jurassic }\end{array}$ & $\begin{array}{l}\text { Limestone, } \\
\text { limestone with } \\
\text { cherts, } \\
\text { karstified and } \\
\text { fissured } \\
\text { dolomites }\end{array}$ & $\begin{array}{l}\text { II_Fissured or porous } \\
\text { Fissured Aquifers a- } \\
\text { with widespread strata } \\
\text { with high productivity }\end{array}$ & $60-70$ & $\begin{array}{c}\text { High } \\
\text { Productivity }\end{array}$ & High & Variable & High \\
\hline $\mathrm{Pg}_{2}{ }^{3}$ & $\begin{array}{l}\text { Middle } \\
\text { Oligocene }\end{array}$ & $\begin{array}{l}\text { Clays, } \\
\text { siltstones, } \\
\text { sandstones, } \\
\text { coral } \\
\text { calcareous, } \\
\text { marls and } \\
\text { brown coals. }\end{array}$ & $\begin{array}{l}\text { III_Fissured or porous } \\
\text { rocks with local and } \\
\text { limited groundwater } \\
\text { resources or rocks } \\
\text { essentially poor with } \\
\text { groundwater } \\
\text { resources. b-local } \\
\text { groundwater and low } \\
\text { permeability }\end{array}$ & - & $\begin{array}{l}\text { Variable- } \\
\text { low }\end{array}$ & Low & $\begin{array}{l}\text { Below } \\
0.51 / \mathrm{s}\end{array}$ & Very low \\
\hline $\mathrm{Pg}_{2}{ }^{2}$ & $\begin{array}{l}\text { Middle } \\
\text { Eocene }\end{array}$ & $\begin{array}{l}\text { Flysch, clays- } \\
\text { sandstones }\end{array}$ & $\begin{array}{l}\text { III_Fissured or porous } \\
\text { rocks with local and } \\
\text { limited groundwater } \\
\text { resources or rocks } \\
\text { essentially poor with } \\
\text { groundwater } \\
\text { resources. b-local } \\
\text { groundwater and low } \\
\text { permeability }\end{array}$ & - & Very low & $\begin{array}{l}\text { Very } \\
\text { low }\end{array}$ & $\begin{array}{l}\text { Very } \\
\text { low }\end{array}$ & Very low \\
\hline $\mathrm{Nb}_{1}$ & $\begin{array}{l}\text { Burdiga- } \\
\quad \text { lian }\end{array}$ & $\begin{array}{l}\text { Marls, } \\
\text { limestone }\end{array}$ & $\begin{array}{l}\text { III_Fissured or porous } \\
\text { rocks with local and } \\
\text { limited groundwater } \\
\text { resources or rocks } \\
\text { essentially poor with } \\
\text { groundwater } \\
\text { resources. b-local } \\
\text { groundwater and low } \\
\text { permeability }\end{array}$ & - & $\begin{array}{c}\text { Variable- } \\
\text { low }\end{array}$ & Low & $\begin{array}{l}\text { Below } \\
0.51 / \mathrm{s}\end{array}$ & Very low \\
\hline $\mathrm{J}_{3}$ & $\begin{array}{l}\text { Upper } \\
\text { Jurassic }\end{array}$ & $\begin{array}{l}\text { Limestone, } \\
\text { argillaceous } \\
\text { schist }\end{array}$ & $\begin{array}{l}\text { II_Fissured or porous } \\
\text { Fissured Aquifers. a- } \\
\text { with widespread strata } \\
\text { with high productivity }\end{array}$ & $60-70$ & $\begin{array}{l}\text { High } \\
\text { Productivity }\end{array}$ & High & Variable & High \\
\hline
\end{tabular}

\section{Some clarifications about the map}

At first look, the hydrogeologic map in GIS program (Fig. 4) looks the same as a map one might usually see. One look is all it takes for one to find the division of hydrogeological complexes. These map divisions are explicatory for a hydrogeological specialist or even a geologist, because of the conventional signs in relation to hydrogeology, water-keeping, as well as many other data. At this point the construction of this map, with the abovementioned program, makes this understandable and at the same time usable by all and offers the ability to use exactly the data that one might need.

The original map was completed (already digitized) and the symbols created by the author. A complete hydrogeological map of Prespa's area is now available. This map, apart from the image obtained from the original map, contains the hydrogeological data for each polygon (Table 1). Also, one can find chemical analysis and tables of the samples obtained over the years in the Prespa Lake and the rivers that serve as recharge sources for this area. This map gives accurate hydrogeological presentation just by moving through the various polygons. Furthermore, it also represents a certain geological age assigned to the respective index.

In the hydrogeological map in GIS, there is much more data than can be found in an ordinary map. At the same time one might even find different views of the area, but always within the same structure. By means of this program one can input all the data about the region. Also, one can add 
and change data according to the presented needs or upon bases of further studies of the region in question. Building the map involved substantial amount of work, however, it will not be needed to construct another map of this kind. As it was mentioned earlier the possibility exists that new data can be added, corrected, or replaced without removing the existing ones. The presentation in 3D of Prespa's region makes it easier to locate the low and high zones of relief, as well as the surface and groundwater (Schetselaar, 1995). The program used to construct this map is ArcView 9.2.

In continuity the construction of the map was shown step by step as well as the data with which this map was enriched. At first, the hydrogeological data that are available for this region were included, and then the physical-chemical data of the waters were added (Figure 9, 10). This material was also enriched with respective tables of hydrogeological fields, which in the map are presented by the attributes table of polygons, as well as the tables of the chemical data of the region. The available water chemistry data in the aforementioned region was inputted in the hydrogeological map. The map is constructed using the GIS program.

\section{Results}

\subsection{The hydrogeological map in the GIS program}

The Geographic Information System (GIS) describes a computer system for storing, manipulating, and displaying geographically referenced information (Keenan, 2001). Ordinary paper maps are graphic representations of the real world that all of us have used. City street maps, for example, depict natural objects, such as rivers and lakes; man-made objects such as roads and buildings; and abstract objects such as city or county boundaries. These objects, whether natural, man-made, or abstract, are called map features. Each feature on a map has a location, a representative shape, and a symbol that represents one or more of its characteristics. The meanings of a map's symbols are often depicted in the map's legend.

Features on maps are displayed according to their locations relative to each other and to an underlying grid representing the earth's surface. Specialized maps, such as topographic, soil type, population density, watershed, are used to support specialized decision making tasks (Clapp and Rodriguez, 1997). Most features depicted on a map have attribute information, descriptive data about each feature (polygons in hydrogeological map).

The hydrogeologic map in scale 1:50,000 have been taken by the archive of Albanian Geological Survey and later have undergone processes in the GIS program, where data according to map's profile, are added. At first glance, this map looks ordinary, but as it was mentioned earlier, this map is easy to read by the specialists of respective discipline and is not as clear for a person who does not deal with this discipline. Therefore, the construction of this map using the abovementioned program (GIS) makes this understandable and usable by multi-disciplinary engineers. It enables the possibility for one to see and take only what they need. The objective of the map is to represent the hydrogeologic data of the region. Each polygon of the map represents a specific geologic age. The attribute table contains the hydrogeological data of geologic deposits representing different hydrogeological characteristics.

\subsection{Database in GIS map}

The reason for setting up the hydrogeologic map in the GIS program is to utilize the program's map features. A hydrogeological database was created and inserted in the map (Figs 6, 7, 8). The hydrogeological map was created in a fashion that could be read, understood and studied by multidisciplinary engineers, not necessarily specialists of hydrogeology. The objective to construct such a map was achieved. For future work, this map may be improved by further utilizing the features offered in the GIS program. The tables give the ranges of attributes of hydrogeological data and hydrogeological features for each polygon and are shown in Table 1. 


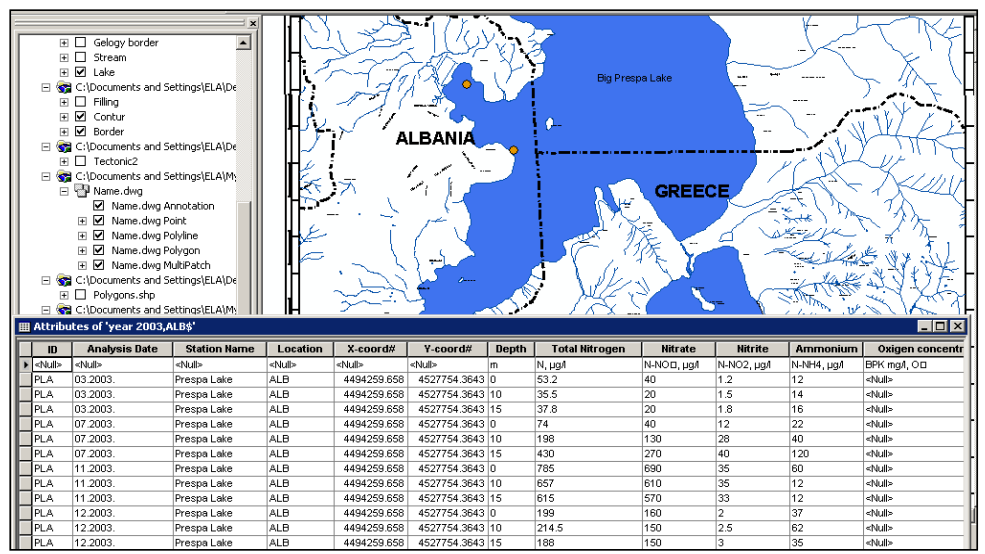

Figure 6 - Points where the samples for chemical analysis in theAlbanian part of the Prespa Lake were taken.

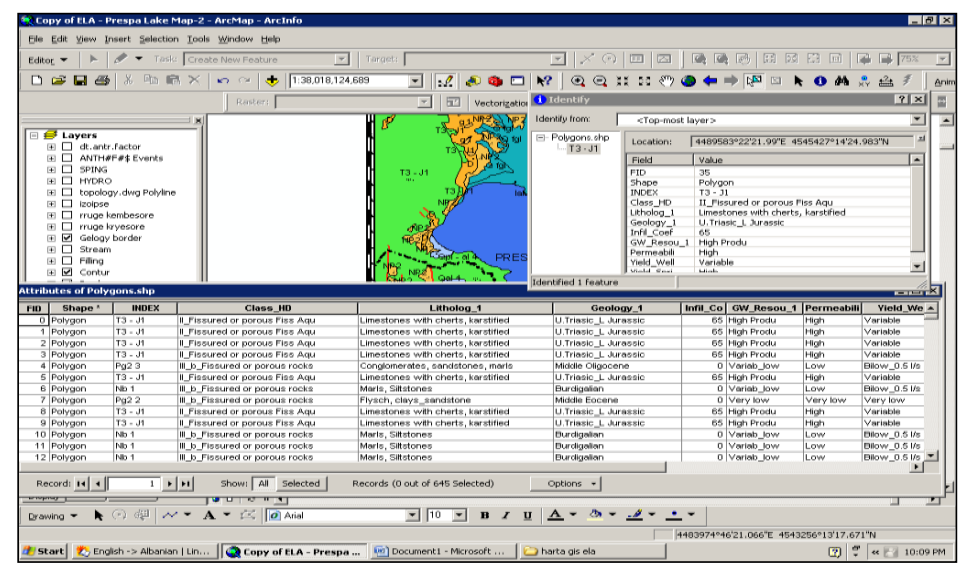

Figure 7 - The identify tab displaying the hydrogeology datafor a selected polygon.

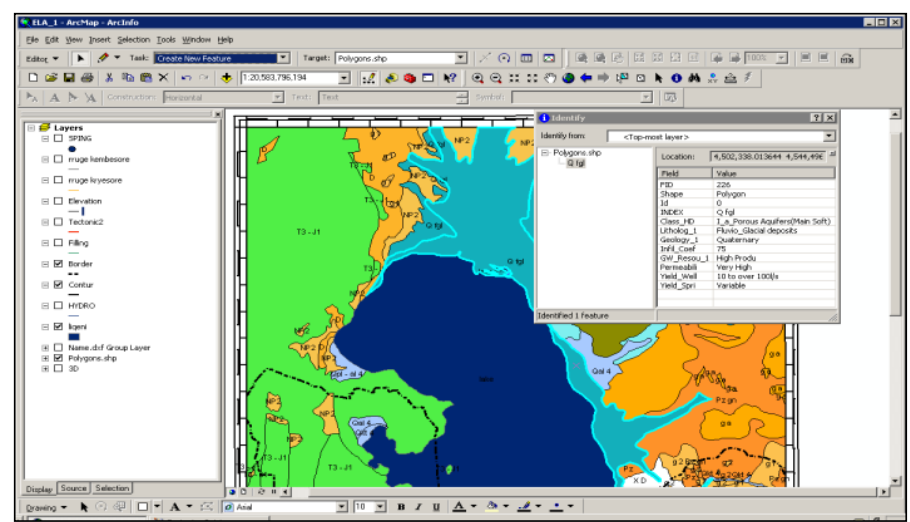

Figure 8 - The identify tab displaying the hydrogeology data for a selected polygon, in this case is Qfgl (fluvial-glacial deposits).

One of the advantages of using the GIS software over conventional drafting packages is the possibility of assigning attributes to each polygon. The attributes of the polygons are recorded in a table associated with the vector file (Schetselaar, 1995). Each polygon has its own index which indicates its geological age. As demonstrated in Fig. 8, by clicking (i), detailed data about 
hydrogeology can be displayed, such as: the geological age, lithology, hydrogeological classification, infiltration coefficient, groundwater resources, permeability, yield of wells and yield of springs. More details can be found in Table 1. In this table each index represents a specific geologic age. In the map one index has his own color, and all this tells a lot for a specialist of hydrogeology. In this case, as one can have already explained, all these data will be in the digital map, making this a very simple for everyone. Hydrogeological classification is based in the general classification of the Albanian Map scale 1:200,000 and at the same time, based in the study made in this area during years. The GIS program uses the concept of layers to represent real world data on a spatial basis. Also, the GIS program uses spatial attributes of data, namely $\mathrm{x}$ and $\mathrm{y}$ coordinates, to represent geographic data (Barraud et al., 2001).

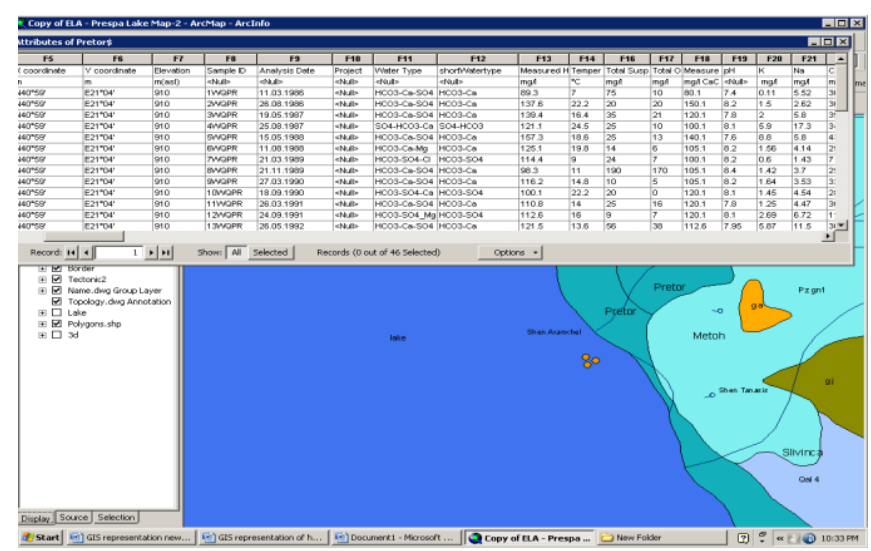

Figure 9 - Database of Pretor-chemical analysis from samples taken in the geographic pionts shown in the map.

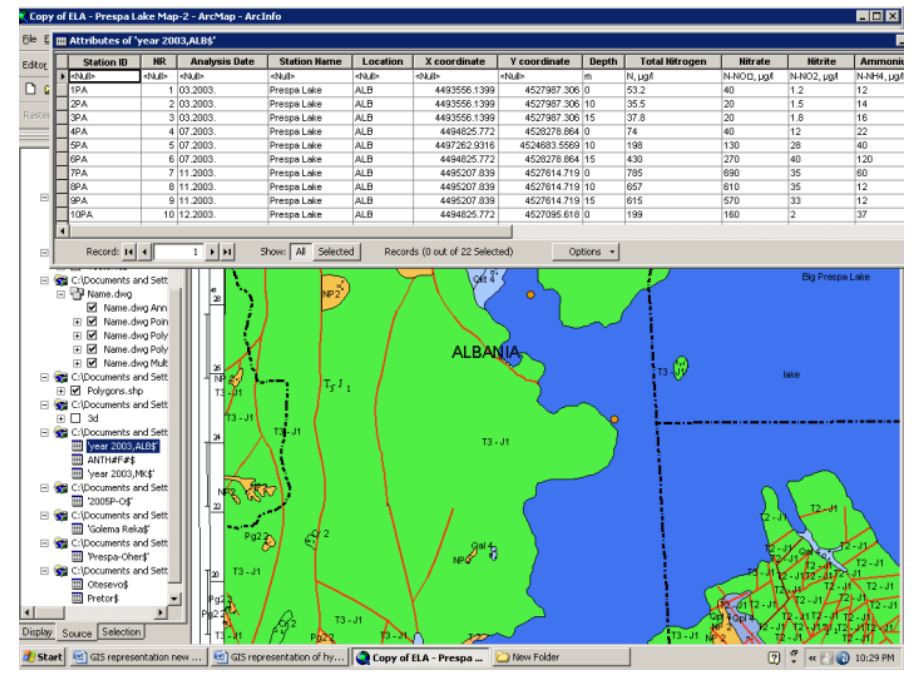

Figure 10 - Database of Albanian part of the Big Prespa Lake-chemical analysis from sample $s$ taken in the geographic pionts shown in the map.

\section{Conclusions-Discussion}

The hydrogeologic map in scale 1:50,000 have been taken by the archive of Albanian Geological Survey (Eftimi et al., 1985 and Geological Map of Greece, scale 1:50,000, IGME, 1997) and later have undergone processes in the GIS program, where data according to map's profile, are added. At first glance, this map looks ordinary, but as it was mentioned earlier, this map is easy to read by the 
specialists of respective discipline and is not as clear for a person who does not deal with this discipline. Therefore, the construction of this map using the abovementioned program (GIS) makes this understandable and usable by multi-disciplinary engineers. It enables the possibility for one to see and take only what they need.

The objective of the map is to represent the hydrogeological data of the region. Each polygon of the map represents a specific geologic age. The attribute table contains the data of geologic formations representing different hydrogeological characteristics (Tafilaj, 1977). The reason for setting up the hydrogeological map in the GIS program is to utilize the program's map features. A hydrogeological database was created and inserted in the map. The hydrogeological map was created in a fashion that could be read, understood and studied by multidisciplinary engineers, not necessarily specialists of hydrogeology. The objective to construct such a map was achieved. For future work, this map may be improved by further utilizing the features offered in the GIS program. The tables give the ranges of attributes of hydrogeological data and hydrogeological features for each polygon (Table 1).

The metadata for each layer of the hydrogeological map built in the GIS program is created. Each polygon has its own index which indicates its geological age. As demonstrated in Fig. 7, detailed data about hydrogeology can be displayed, such as: the geological age, lithology, hydrogeological classification, infiltration coefficient, groundwater resources, permeability, yield of wells and yield of springs. The map meets the demands with existing hydrological and chemical data and the impact of anthropogenic factor in the Prespa Lake and the surrounding area as well. Metadata's have been fulfilled manually for each layer in this map.

Hydrogeological classification included in the map built in GIS in addition to other hydrogeological data may be of great help to specialists using the database of this map in the future. This work may be of great help for any specialists working directly with the specification of their study, without being required to do everything from start. Chemical tables involved in this material and map may in the future be used to study the pollution caused by anthropogenic factors or, if it will be necessary, to estimate the progress of pollution year-after-year. Also these data can be replaced, or added to, if the need arises given the purpose of the study.

\section{Acknowledgement}

I wish to give great thanks to Wessex Institute of Technology, UK (WIT). The support provided by NATO's SfP programme is gratefully acknowledged (NATO Science for Peace Programme project ESP.EAP.SFPP 98 1116).

\section{References}

Barraud, J., 2005. The use of watershed segmentation and GIS software for textural analysis of thin sections, Journal of Volcanology and Geothermal Research, 154(1-2), 17-33.

Benedikt, J., Reinberg, S. and Riedl, L., 2002. A GIS application to enhance cell-based information modeling, Information Sciences, 142(1-4), 151-160.

Clapp, M.J. and Rodriguez, M., 1997. How GIS Can Put Urban Economic Analysis on the Map, Journal of Housing Economics, 6(4), 368-386.

Cox, B.A. and Gifford, F., 1997. An overview to Geographic Information Systems, The Journal of Academic Librarianship, 23(6), 449-461.

Eftimi, R., Tafilaj, I., and Bisha, G., 1985. Hydro-geological Map of Albania, Scale 1:200,000, Tirana, Bul. Shk. Geol. Geological Sciences Bulletin, 4, 133-148.

Eftimi, R. and Zoto, J., 1997. Isotope study of the connection of Ohrid and Prespa lakes, International Symposium "Towards Integrated Conservation and Sustainable Development of Transboundry Macro and Micro Prespa Lakes", Symposium held in Korca, Albania, 32-37.

Eftimi, R., 2003. Hydrogeology of Small Prespa Lake watershed, In: investigation of the upper part of Devoll River watershed. Korce, 1-17. 
Eftimi, R. and Zojer, H., 2015. Human impacts on karst aquifers of Albania, Environmental Earth Sciences, 74, 57-70.

IGME, 1997. Geological Map of Greece, scale 1:50,000, Koritsa - Mesopotamia sheet, Podgori Andratikon sheet.

Keenan, P., 2001. Geographic Information Systems, University College, Dublin, Encyclopedia of Information Systems, 421-432.

KfW Feasibility Study, Project Preparation \& Development of the, Transboundary Prespa Park Project, 2004. KfW Entwicklungsbank, Frankfurt, 4(1), 11-39, 4(4), 3-30.

Kiri, E., 2010. GIS representation of hydrogeological and chemical data for international waters of Prespa Lake, Master Thesis, Wessex Institute of Technology, University of Wales, UK.

Matzinger, A., Jordanoski, M., Veljanoska-Sarafilovska, E., Sturm, M., Muller, B. and Wuest, A., 2006. Is Lake Prespa jeopardizing the ecosystem of ancient Lake Ohrid? Hydrobiologia, 89109.

Ramsar, 2000. Lake Prespa. www.ramsar.org.

Ranger, R., Cimetta, A., Pettygrove, S. and Rogan, S., 2002. Geographic Information Systems (GIS) as an evaluation tool, American Journal of Evaluation, 23(4), 469-479.

Tafilaj, I., 1977. Hydrogeological classification of mines of Albania (In Albanian), Permb. Stud., Tirana, 1, 190-121.

Sheppard, E., 2004. Geographic Information Systems: Critical Approaches, International Encyclopedia of the Social \& Behavioral Sciences, 6182-6185.

Schetselaar, E.M., 1995. Computerized field-data capture and GIS Analysis for generation of cross sections in 3-D perspective views, Netherlands, Computers \& Geosciences, 21(5), 687-701.

Voudouris, K., Kazakis, N., Polemio, M. and Kareklas, K., 2010. Assessment of intrinsic vulnerability using DRASTIC model and GIS in the Kiti aquifer, Cyprus, European Water, 30, 13-24. 